\title{
'In divinis scripturis legitur': monastieke idealen en het gebruik van de Bijbel in de Gesta Sanctorum Rotonensium
}

\section{Rutger Kramer,}

R.D. Kramer, MPhil, is promovendus aan de Freie Universität Berlin/Université de Limoges/Universiteit Utrecht

Wanneer de monnik Condeluc, tuinman van het klooster van Redon, in het zuidoosten van het tegenwoordige Bretagne, wordt geconfronteerd met een invasie van rupsen in de kloostertuin, is hij in eerste instantie in alle staten. Hij was juist gekozen voor deze belangrijke functie omdat hij vanwege zijn exceptionele deugdelijkheid goed zou kunnen zorgen voor de groenten en kruiden van de gemeenschap, en nu zouden zijn goede werken teniet gedaan worden door een plaag van welhaast bijbelse proporties. In plaats van bij de pakken neer te zitten, behoudt Condeluc echter zijn geloof. In tranen spreekt hij de rupsen aan, en beveelt ze, volgens de auteur, "in de naam van de Vader, de Zoon en de Heilige Geest om niet langer meer te blijven, maar om zo snel mogelijk weg te gaan van deze plaats". Zijn plan slaagt, de rupsen vertrekken, en de monnik dankt de Heer voor diens hulp. Enige jaren later sterft hij. Op een zondag.

Dit verhaal is terug te vinden in de zogeheten Gesta Sanctorum Rotonensium, "De Daden van de Heiligen van Redon", een beschrijving van de eerste decennia van het bestaan van een klooster op de grens tussen de Bretonse en Frankische invloedssferen, die in zijn vroegste vorm waarschijnlijk dateert uit het laatste kwart van de negende eeuw. ${ }^{1}$ Hoewel het werk deze titel pas in de zeventiende eeuw heeft gekregen van de onvolprezen Jean Mabillon, lijkt de aanduiding op het eerste gezicht juist. ${ }^{2}$ In het werk

1 Gesta Sanctorum Rotonensium, ed. en vert. Caroline Brett, The monks of Redon: Gesta Sanctorum Rotonensium andVita Conuuoionis (Woodbridge 1989). De editie en vertaling zijn te vinden op pp. I06-219

2 Ed. Jean Mabillon, Acta Sanctorum Ordinis Sancti Benedicti IV.2 (Parijs 1680), 184-222. Excerpten zijn ook te vinden als Ex Gestis Conwoionis Abbatis Rotonensis, ed. L. de Heinemann, Monumenta Germaniae Histori- 
worden, in de loop van een drietal boeken, inderdaad de daden van de eerste generatie monniken beschreven, in ogenschijnlijk chronologische volgorde, beginnend bij de stichting en de problemen die daarbij komen kijken en culminerend in een scène waarin de beschermheiligen van het klooster de gemeenschap redden van een aanval door een hordeVikingen. ${ }^{3}$ Daartussen worden ook de wonderen verricht door de levende monniken beschreven, waarvan de wonderbaarlijke rupsenverdrijving er één is.

De Gesta Sanctorum Rotonensium (GSR) gaat echter dieper dan louter narratieve beschrijvingen. In de loop van dit artikel hoop ik te laten zien dat de auteur van dit werk niet alleen heeft gepoogd de geschiedenis van zijn gemeenschap te beschrijven, maar ook om commentaar te leveren op de wereld buiten de muren van het klooster, om zijn publiek een 'spiegel voor monniken' voor te houden en om duidelijk te maken dat Redon niet zomaar een beginnend klooster was, maar een ware locus sanctus, een heilige plaats, onlosmakelijk verbonden met de wonderlijke zaken die er volgens hem zijn gebeurd. ${ }^{4}$ Dit alles zou ertoe moeten leiden dat Redon de eeuwen zou weten te trotseren zonder de nalatenschap van die eerste generatie "heiligen" te verkwanselen.

In het geval van de GSR is het mogelijk deze schrijfdoelen te duiden aan de hand van de vele bijbelcitaten en -allusies die de auteur in zijn narratief heeft verwerkt. Een tweede doel van dit artikel is derhalve om aan te tonen dat dergelijke citaten meer zijn dan alleen maar een reflectie van het feit dat de schrijver goed bekend was met de inhoud van de Bijbel. Met de kennis van zijn beoogde publiek in het achterhoofd, heeft de auteur van de GSR de door hem gebruikte citaten niet toevallig gekozen. De associaties die elk van de 108 bijbelse citaten bij het horen, lezen, of overdenken van de tekst, zou oproepen, beinvloedden voor hen de verhalen op subtiele (of minder subtiele) wijze. Door ze bewust, dus op het juiste moment in te zetten, kon de auteur zijn werk één of meerdere extra lagen van betekenis meegeven en al doende zijn publiek stof tot nadenken leveren.

$\mathrm{Na}$ een kort overzicht van de historische context waarin de GSR is geschreven en enige beschouwingen over het gebruik van de Bijbel in de negende eeuw, zal aan de hand van enkele voorbeelden worden betoogd dat de citaten in de GSR een grotere rol hebben in het verhaal dan pure illustratie en dat zowel deze bron als dergelijke citaten in het algemeen wellicht meer aandacht verdienen dan tot dusverre het geval is geweest.

\section{Een kleine wereld? De stichting van Redon en het ontstaan van de GSR}

Rond het jaar 830 besluiten de Bretonse edelman Conwoion en vijf metgezellen om een klooster te stichten aan de rivier deVilaine, op de grens van de tegenwoordige Franse régions Bretagne en Pays-de-la-Loire. Destijds, bijna twaalf eeuwen geleden, was dit ook al een grensgebied, hoewel er toen heel wat meer speelde dan alleen administratieve kwesties: het Armoricaanse schiereiland en zijn inwoners waren de heersers van het

ca Scriptores 15.I (Hannover 1887), 455-459.Voor het genre, zie M. Sot, Gesta Episcoporum, Gesta Abbatum (Turnhout I98I).

3 Voor een observatie over de chronologie van het werk, zie beneden, p. ro, n. 38.

4 Cf. J. Smith, 'Aedificatio sancti loci: the making of a ninth-century holy place' in: M. de Jong e.a. (eds.), Topographies of power in the early middle ages (Leiden e.a. 200I), 36I-396. 
Frankische Rijk al een flinke tijd een doorn in het oog, om de simpele reden dat het hen maar niet lukte om dit gebied goed onder de duim te houden. Ook al wordt in het werk van Gregorius van Tours beweerd dat de Bretons al sinds de regering van Clovis onder Frankische hegemonie vallen en zijn er uit de Karolingische periode ook verschillende bronnen die aangeven dat er succesvolle militaire campagnes zijn gevoerd tegen de Bretons, het is duidelijk dat er een zekere discrepantie moet hebben bestaan tussen de Frankische beweringen en de praktijk van alledag. ${ }^{5}$

Of dit nu is terug te voeren op een vermeende Keltische oorsprong van de bewoners van het schiereiland (hetgeen in de negentiende en twintigste eeuw vaak als verklaring is opgevoerd voor de verschillen tussen de "etnische" Bretons en hun Franse buren), of dat de lokale heersers in het gebied gewoon slim gebruik wisten te maken van de situatie in het Frankische Rijk om hun politieke onafhankelijkheid te handhaven, uit de bronnen blijkt in ieder geval dat Bretagne een gebied was om in de gaten te houden. ${ }^{6}$ De politieke en militaire steun uit dit gebied kon het machtsevenwicht in het westen van het Frankische rijk terdege beïnvloeden. Dit werd bijvoorbeeld duidelijk toen de Bretonse heerser Salomon (r. 857-874) steun verleende aan Robert de Sterke (r. 853-866) toen deze in 857 in opstand kwam tegen Karel de Kale (r. 840-877), alleen maar om er zelf sterker uit naar voren te komen. ${ }^{7}$ Vóór die tijd, ten tijde van de stichting van Redon, was dit niet anders, en waarschijnlijk is het juist daaraan te danken dat het klooster in 832 niet alleen de steun van de toenmalige Bretonse heerser Nominoë (r. 83I-85I), maar ook van de Karolingische keizer Lodewijk de Vrome (r. 8I4-840) wist te krijgen. ${ }^{8}$

Echt verrassend kan deze beslissing van Lodewijk deVrome niet genoemd worden. Gezien het lastige parket waar hij zich in het laatste decennium van zijn regeerperiode in bevond, is het zelfs een indicatie van zijn no-nonsense aanpak van de grensgebieden. In plaats van voor de zoveelste keer te proberen het achterland van Neustrië gewapenderhand onder de duim te krijgen, had hij de lokaal bekende Nominoë tot zijn missus in het gebied benoemd, waarmee in feite de status quo werd erkend. Steun verlenen aan een nieuw klooster, op de grens tussen beide invloedssferen - deVilaine was traditioneel gezien het punt vanwaaruit veldtochten tegen de Bretons begonnen - paste prima in deze pacificatiepolitiek. ${ }^{9}$

Natuurlijk kon het voor de monniken op hun beurt ook geen kwaad om een steuntje in de rug te krijgen van zowel de lokale heerser als van de keizer, zelfs al had die medaille een keerzijde. Uit de GSR komt naar voren dat deze nieuwe stichting niet bij iedereen in de kleine wereld van zuidoost Bretagne in goede aarde gevallen moet zijn. Immers, op het moment dat Redon gesticht werd, moeten de machts- en bezitsverhou-

5 Voor een overzicht van deze moeizame verhouding, zie J.M.H. Smith, Province and empire: Brittany and the Carolingians (Cambridge 1992). Specifieker over Redon is H. Guillotel en A. Chédeville, La Bretagne des saints et des rois, Ve-Xe siècle (1984), 240-243.

6 N.-Y. Tonnerre, 'L'aristocratie du royaume breton' in: R. Le Jan ed., La royauté et les élites dans l'Europe Carolingienne (début IXè siècle aux environs de 92o) (Lille 1998), 487-504.

7 Smith, Province and empire, 103-105.

8 J.M.H. Smith, 'Culte impérial et politique frontalière dans la vallée de laVilaine:le témoinage des diplômes carolingiens dans le Cartulaire de Redon' in: Landévennec et le monachisme Breton dans le Haut Moyen Âge (Landévennec 1986), I29-I40.

9 Smith, Province and empire, 82. 
dingen in de regio min of meer duidelijk geweest zijn. ${ }^{10}$ Een nieuw klooster, met de potentie om uit te groeien tot een invloedrijke speler, verstoorde de fragiele balans in de regio, en kon rekenen op de nodige tegenstand van de lokale adel - of machtierns, zoals ze in het Bretons genoemd worden. ${ }^{11}$ Uit de manier waarop Nominoë in de GSR is neergezet, alsmede uit de oorkondes die hij voor Redon heeft uitgevaardigd, komt naar voren dat, volgens de monniken althans, de steun van Nominoë heeft geholpen deze vijandigheid het hoofd te bieden, terwijl Lodewijk deVrome en zijn nazaten ervoor gezorgd hebben dat de Frankische adel aan de andere kant van de grens Redon ook de nodige rust liet. ${ }^{12}$

Een gevolg van de Karolingische steun was echter wel, dat het klooster - bewust of onbewust - zou gaan dienen als een 'doorgeefluik' van Frankische cultuur naar de Bretons. ${ }^{13}$ Hierin stond Redon niet alleen. Andere kloosters, zoals bijvoorbeeld het westelijk gelegen Landévennec, golden ook als punten vanwaaruit de Karolingische monastieke en culturele hervormingen zich verspreidden over het schiereiland. ${ }^{14}$ Dit kan niet onopgemerkt zijn gebleven, en zou zelfs een extra reden geweest kunnen zijn voor de lokale machthebbers om de groei van de gemeenschap met argusogen te bekijken, al was het maar vanuit politiek perspectief. Cultureel gezien lag Redon immers niet zozeer op een grens als wel midden in een grijs gebied waarin het niet alleen onmogelijk, maar ook zinloos zou zijn om te proberen te achterhalen waar 'Bretons' begon en 'Frankisch' ophield. ${ }^{15}$

Toen Conwoion in 868 stierf, liet hij een klooster na dat er in was geslaagd om uit te groeien tot een belangrijke speler in het lokale politieke en culturele leven. Dit proces kan goeddeels getraceerd worden aan de hand van het beroemde Cartularium van Redon, een verzameling oorkondes die is samengesteld in de late elfde eeuw, maar die teruggaat tot de vroegste periode van het klooster. ${ }^{16}$. Hiernaast moet, kort na de dood van Conwoion, een monnik besloten hebben dat de gemeenschap compensatie nodig had voor het wegvallen van deze zo belangrijke abt. In de decennia na 868 werd dan ook een begin gemaakt met de GSR, bedoeld om niet alleen de geschiedenis van Redon tot dan toe te beschrijven, maar ook om de komende generaties van monniken een beeld te geven van de eerste zes exemplarische heiligen, om ze aan te sporen toch vooral in hun voetsporen te treden. Dit zou niet de enige keer zijn dat in Redon - of in andere kloostergemeenschappen, overigens - naar de pen werd gegrepen om in het verleden

10 Cf.W. Davies, Small worlds: the village community in early medieval Brittany (London 1988).

11 Davies, Small worlds, r8I.

12 Voor een voorbeeld van die vijandigheid, zie beneden, p. Io.

13 P. Riché,'Les hagiographes bretons et la renaissance carolingienne' Bulletin Philologique et Historique (I968), 65I-659; dat dit verschijnsel niet beperkt bleef tot het Bretonse grensgebied, wordt o.a. getoond in M. de Jong, 'Charlemagne's church' in:J. Story (ed.), Charlemagne: empire and society (Manchester e.a. 2005), 103-135, aldaar $120-122$.

14 H. Guillotel, 'Les origines de Landévennec' in: Landévennec, 97-114, aldaar 100.

15 T.FX Noble, 'Louis the Pious and the frontiers of the Frankish realm' in: P. Godman e.a. (eds.), Charlemagne's heir: new perspectives on the reign of Louis the Pious (814-840) (Oxford 1990), 333-347; W. Davies, 'On the distribution of political power in Brittany in the mid-ninth century' in: M. Gibson en J. Nelson (eds.), Charles the Bald:court and kingdom, papers based on a colloquium held in London in April 1979 (London I98I), 87-107,aldaar 87-88.

16 Cartulaire de l'Abbaye Saint-Sauveur de Redon, eds. H. Guillotel e.a. (facsimile, Rennes I998). 
naar legitimatie voor de toekomst te zoeken, of om de gemeenschapszin te consolideren. ${ }^{17}$ De compositie van het Cartularium kan geplaatst worden in de context van de terugkeer van de monniken nadat ze voor Vikingen hadden moeten vluchten, en dus als een poging hun eerdere glorie, alsmede hun bezittingen, te herwinnen. ${ }^{18}$ Dat het oudste manuscript van de GSR, alsmede een bewerking ervan tot de zogenaamde Vita Conwoionis, het 'Leven van Conwoion' ook uit deze tijd dateren, lijkt te bevestigen dat de monniken in deze periode een hernieuwde interesse in hun geschiedenis toonden. ${ }^{19}$ Vanaf het moment dat de tekst is opgeschreven, kan dus gesteld worden dat de GSR als het ware zélf een acteur binnen de gemeenschap is geworden, dat er een interessante wisselwerking ontstaat tussen de tekst en de interpretatie van die tekst door het publiek. ${ }^{20}$ Wanneer specifiek gekeken wordt naar het "moment of inscription", kan een tekst als de GSR dus gezien worden als een actieve poging van een lid van de gemeenschap om zijn publiek een boodschap over te brengen met een zo breed mogelijk draagvlak. ${ }^{21} \mathrm{Dit}$ artikel concentreert zich met name op dit moment van schrijven, waarin zowel de auteur als zijn tekst als acteurs in Redon optraden en ons een blik gunnen op de manier waarop hij Redon zag op het moment van schrijven

De GSR zelf is een vrij kort, eclectisch werk waarin elementen uit historiografische tradities, hagiografie en gesta-literatuur samenkomen. Een dertigtal verhalen is verdeeld over drie boeken, waarvan het eerste de periode van stichting van het klooster tot en met de erkenning door Lodewijk de Vrome behandelt, het tweede verhaalt van de wonderlijke daden van de nog levende monniken, en het derde van de wonderen van de relieken van paus Marcellinus en St. Hypothemius van Angers. Hiernaast worden boeken 2 en 3 voorafgegaan door een proloog, waaruit blijkt dat het de bedoeling van de auteur is geweest om te eindigen met de dood van Conwoion. Om onbekende redenen is dit bedoelde einde echter verloren gegaan, of nooit voltooid. Daarnaast ontbreken de inleiding en eerste hoofdstukken van het eerste boek - uit passages in de overgeleverde tekst, waarin de auteur ervan uit lijkt te zijn gegaan dat de lezer beschikt over informatie die in de ontbrekende eerste hoofdstukken zou hebben gestaan, zou blijken dat dit begin al vroeg verloren is gegaan. ${ }^{22}$ Hierdoor blijft helaas het nodige over

17 Een goed voorbeeld en een uitstekende methodologische uitleg wordt gegeven in Walter Pohl's artikel over de historiografie van Montecassino: 'History in fragments: Montecassino's politics of memory', Early Medieval Europe I0:3 (2001), 343-374-

18 Cf. de inleiding bij de facsimile-editie, alsmede G. Declercq, 'Originals and cartularies: the organization of archival memories (ninth-eleventh centuries)' in: $\mathrm{K}$. Heidecker ed., Charters and the use of the written word in medieval society (Turnhout 2000), I47-I7I.

19 Brett, Monks of Redon, $2 \mathrm{I}-27$.

20 Zie hierover bijvoorbeeld Stuart Airlie, 'Sad stories of the death of kings: narrative patterns and structures of authority in Regino of Prün's Chronicle' in: Elizabeth M. Tyler en R. Balzaretti, Narrative history in the early medieval West (Turnhout 2006), IOS-131, aldaar II2.

21 Zie hierover G. Spiegel, 'History, historicism and the social logic of the text', Speculum 65 (1990), 59-86, en voor een praktijkvoorbeeld over Sankt-Gallen, Matthew Innes, 'Memory, orality and literacy in an early medieval society', Past and Present 158 (1998), 3-36.

22 Brett, Monks of Redon, 6; GSR, 1.3, II4-II5; steeds als er nieuwe personen worden geïntroduceerd, gaat dat gepaard met een korte ornschrijving. Voor de edelman Risweten, die, getuige het cartularium, het land doneerde waarop het klooster is gesticht, gebeurt dat niet. Aangezien de stichting van Redon zelf ook niet in de GSR te vinden is, wordt aangenomen dat dat in een verloren hoofdstuk gestaan moet hebben. 
de intenties van de auteur onduidelijk. Uit de overgebleven manuscripten blijkt echter wel dat het werk hoofdzakelijk is gebruikt in Redon zelf - alle versies vinden daar hun oorsprong. Hiernaast wordt in een laat- $17^{\mathrm{e}}$-eeuwse kopie, waarschijnlijk gemaakt door een op locatie werkende Maurist, nog gewag gemaakt van een tweede middeleeuws manuscript, dat mogelijk nog ouder was dan het elfde-eeuwse exemplaar dat nu nog bestaat. Wat er is gebeurd tussen het tijdstip waarop de kopie werd gemaakt en het jaar 1898 , toen de Bibliothèque Nationale het oudste manuscript kocht uit de erfenis van Jérôme Pichon, is niet duidelijk, maar het lijkt erop dat de Franse Revolutie ook haar sporen heeft nagelaten in Redon en zijn manuscripten. ${ }^{23}$

Het Latijn van de auteur van de GSR is makkelijk te volgen, en getuigt van een zekere mate van ontwikkeling. Dit blijkt ook uit het feit dat hij niet wars is van een zeker intellectualisme en zelfs tot twee keer toe een grecisme in zijn verhaal weet te verwerken. ${ }^{24}$ Hiernaast blijkt uit de werken die direct geciteerd worden, dat de auteur bekend was met onder andere de Dialogen van Gregorius de Grote, het exegetische werk van Beda Venerabilis, en de Vita Martini van Sulpicius Severus. ${ }^{25}$ Het is in deze ook interessant om op te merken dat in hoofdstuk I.3 een complete passage uit de Vita Philiberti, stichter van Jumièges en Noirmoutier, is overgenomen, en dat in hoofdstuk 2. Io een fragment uit het Liber Pontificalis terug te vinden is. Buiten deze directe invloeden is ook duidelijk dat de auteur, zoals te verwachten, bekend was met de Regula Benedicti en de Bijbel. ${ }^{26}$

\section{Bijbelgebruik en bronnen Redon: een poging tot reconstructie?}

Het behoeft bijna geen verdere uitleg dat monniken in de negende eeuw goed bekend waren met de inhoud van de heilige Schrift.Van de wekelijks terugkerende liturgie tot de laatste opmerking in de Regula Benedicti dat in de heilige Schrift uiteindelijk de enige juiste leefregels staan, het monastieke leven draaide uiteindelijk om hetgeen in de Bijbel te vinden was. ${ }^{27}$ In de negende eeuw, toen de Karolingische religieuze hervormingsbeweging in volle gang was, was dit niet anders. ${ }^{28}$ Intellectuelen aan het hof deden verwoede pogingen om de tekst van de Bijbel vrij te maken van fouten die er ingeslopen zouden kunnen zijn, zodat er bij het vieren van de liturgie of het interpreteren van de Bijbel in ieder geval van een correcte tekst uitgegaan kon worden. Het feit dat de meeste

23 Brett, Monks of Redon, 22 en 28-30.

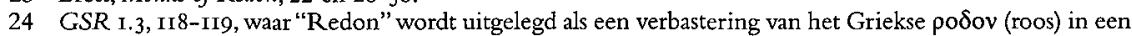
passage die grotendeels is gekopieerd uit de Vita Philiberti, en GSR I.9, I34-I35, waar een vrouw wordt angeduid als "apodix, id est meretrix". De etymologie van "apodix" is onduidelijk, maar zowel Brett, Monks of Redon, 84, als Pierre Riché, 'En relisant l'Histoire des saints de Redon' in: Landévennec et le Monachisme Breton, I3-I8, vermoeden een Griekse oorsprong - of in ieder geval een poging van de auteur om dat te suggereren.

25 Brett, Monks of Redon, $64-69$

26 Ibid., 70-90.

27 Regula Benedicti, 73:3 in: Die Benediktusregel, Lateinisch/Deutsch, hg. im Auftrag der Salzburger Äbtekonferenz, (Beuron, I992), 294-295; S. Boynton, 'Training for the liturgy as a form of monastic education' in: G. Ferzoco e.a. (eds.), Medieval monastic education (London e.a. 2000), 7-20, wijst ook op de plaats die de Bijbel, en dan met name de Psalmen, innemen in het monastieke leven.

28 J.J. Contreni, 'Carolingian biblical studies' in: U.-R. Blumenthal (ed.), Carolingian essays: Andrew W. Mellon Lectures in early Christian studies (Washington DC 1983), 71-98. 
citaten uit de Psalmen in de GSR overgenomen zijn uit het Psalterium Romanum en niet uit de Vulgaat, geeft wel al aan dat er in Redon, net zo min als in de rest van het Karolingische rijk, consensus over de precieze tekst bereikt was, en dat het niet mogelijk was om één van de oude versies boven de anderen te plaatsen. ${ }^{29}$ Belangrijker in deze context was het om de teksten uit de biblia sacra correct te interpreteren, omdat alleen daarin te vinden was hoe men een goed christen in een goed christelijk keizerrijk diende te zijn. ${ }^{30}$

Voor de exegese van de Bijbel in de Karolingische periode waren de patristische commentaren van doorslaggevende invloed. Dit heeft geleid tot negatieve karakteriseringen zoals verwoord door bijvoorbeeld McNally: "too firmly constructed on the principle that Christian antiquity in itself is an infallible authority for all things". ${ }^{31}$ Deze visie doet echter geen recht aan de intellectuelen van de negende eeuw, aangezien juist de manier waarop de oudere, eerbiedwaardige bronnen werden hergebruikt, hun werk - bij gebrek aan een beter woord - zo origineel maakte. ${ }^{32}$ Dit gold niet alleen voor auteurs van bijbelcommentaren, maar ook, zoals we zullen zien, voor de schrijvers van hagiografische werken. Het was immers de bedoeling dat ook deze verhalen een onderwijzende functie zouden hebben. De lessen die het publiek mee diende te krijgen, werden extra kracht bijgezet door de Bijbel en de gangbare interpretaties ervan op strategische punten in te zetten. ${ }^{33}$ Het grote verschil met puur exegetische werken was, dat in hagiografie de Bijbel niet per se uitgelegd hoefde te worden. Belangrijker was het, om deze uitleg in praktische zin toe te passen: als het beoogde publiek, in dit geval een groep monniken met eenzelfde achtergrond als de auteur, de Bijbel begreep zoals de auteur dat deed, dan zou de voorbeeldfunctie van de exempla hen ook duidelijk worden.

Dat dit fenomeen inderdaad zo werkte, en dat de invloed van patristische interpretaties niet onderschat dient te worden, is in 1987 aangetoond in Marc van Uytfanghe's Stylisation Biblique et Condition Humaine, waarin hij het gebruik van de Bijbel in Merovingische hagiografische werken onder de loep nam. ${ }^{34}$ Van Uytfanghe liet zien dat citaten uit de Bijbel niet zomaar werden gebruikt. Ze dienden als signalen voor het publiek, dat de allusie zou herkennen en daarmee ook het punt van het verhaal zoals beoogd door de auteur.Vaak volstond het om de context waarin het citaat in de Bijbel te vinden is, te herkennen, maar net zo vaak ging het erom, te weten hoe de auteur daarmee om placht te gaan. Zijn analyse richtte zich weliswaar op de Merovingische periode, maar de door hem gebruikte methode is mijns inziens goed bruikbaar voor de periode waarin de GSR werd geschreven. Dat betekent, dat, om een idee te krijgen van

29 Voor een beschrijving van de veelvormigheid van de karolingische kerk, waarin ook de plaats van de verschillende versies van de Bijbel wordt behandeld, zie R. McKitterick, 'Unity and diversity in the Carolingian church' in: R.N. Swanson (ed.), Unity and diversity in the Church (Oxford 1996), 59-82, aldaar 64.

30 M. de Jong, 'The Empire as 'ecclesia'. Hrabanus Maurus and biblical historia for rulers' in:Y. Hen e.a (eds.), The uses of the past in the early middle ages (Cambridge 2000), $191-226$.

31 R. E. McNally, The Bible in the early middle ages (Westminster 1959), 79 .

32 J.Heil, 'Labourers in the Lord's quarry: Carolingian exegetes, patristic authority, and theological innovation - a case study in the representation of Jews in commentaries on Paul' in: C. Chazelle e.a. (eds.), The study of the Bible in the Carolingian era (Turnhout 2003), 75-95, aldaar 77-78 en 95.

33 E. Ann Matter, 'The Bible in early medieval saints' lives' in: Chazelle e.a (eds.), Study of the Bible, IS5-165.

34 M.van Uytfanghe, Stylisation biblique et condition humaine dans l'hagiographie Mérovingienne (600-750) (Brussel 1987). 
de gedachtenwereld van de auteur, ook hier primair gekeken moet worden naar de manier waarop patristische commentaren en ideeën tekst en uitleg geven bij de gekozen citaten.

$\mathrm{Nu}$ is het niet zo, dat het voldoende is om simpelweg te kijken naar de populairste kerkvaders in de negende eeuw en hun visie aan de auteur van de GSR op te leggen. Het is immers nauwelijks te doen om de precieze receptie van hun gedachtengoed in het algemeen te reconstrueren - laat staan voor één bepaald klooster, waarvan niets bekend is van het boekenbezit. ${ }^{35}$ De analyse in dit artikel heeft derhalve een ietwat hypothetisch karakter. De voorgestelde werkwijze beoogt een reconstructie van lezing en interpretatie van de GSR door de negende-eeuwse monniken van Redon, door in kaart te brengen hoe patristische commentaren mogelijkerwijs hebben doorgeklonken in de aangehaalde bijbelcitaten.Dit moet leiden tot een beter begrip van deze en soortgelijke hagiografische teksten.

Wat dat betreft is de GSR een uitstekend beginpunt, juist omwille van het feit dat de Bijbelcitaten er zo expliciet in gemaakt zijn. Ze zijn dus makkelijk te herkennen, en ook makkelijk te plaatsen, door zowel middeleeuwse toehoorders als moderne onderzoekers. Waar een citaat duidelijk afwijkt van het "Bijbelse origineel", zou dat kunnen wijzen op het gebruik van een andere bron, zeker wanneer er ook inhoudelijke parallellen zijn. Dat in ieder geval Gregorius de Grote op die manier door de auteur gebruikt is, is bijvoorbeeld af te lezen aan de manier waarop 2 Tim 2:5 wordt aangehaald in hoofdstuk I.9 van de GSR. Het blijkt dan dat de auteur niet letterlijk uit de Bijbel heeft geciteerd, maar heeft gekozen voor een parafrase zoals die terug te vinden is in de Homeliae in Evangelia van Gregorius de Grote. ${ }^{36}$ Juist door die associatie geeft de auteur een signaal aan zijn publiek dat dit verhaal, dat ogenschijnlijk handelt over de manier waarop Conwoion trachtte de keizer voor zich te winnen, ook een waarschuwing is om niet te veel vertrouwen te hebben in menselijke wetten, en dat monniken continu het hoofd moeten bieden aan de verlokkingen van de wereld - want dat is de interpretatie die Gregorius hieraan geeft.Voor de hedendaagse onderzoeker is het daarnaast ook een teken dat deze allusie meer beoogde dan alleen het oproepen van de bijbelse context, iets wat voor meer werken uit de negende eeuw op lijkt te zijn gegaan. ${ }^{37}$

Meer in het algemeen valt ook op aan de GSR dat sommige werken en denkbeelden duidelijk van invloed zijn geweest op de auteur. De Dialogen van Gregorius de Grote, bijvoorbeeld, worden weliswaar betrekkelijk weinig letterlijk geciteerd, maar de parallellen tussen beide werken zijn legio. ${ }^{38}$ Hetzelfde geldt voor Beda, wiens werk bekend

35 Een voorbeeldige studie zoals die naar de Vita Adalhardi en de Epitaphium Arsenii, in: David Ganz, Corbie in the Carolingian Renaissance, Beihefte der Francia 20 (Sigmaringen 1990), 103-120, ligt dus helaas buiten ons bereik.

36 Gregorius, Homeliae in Evangelia 37, ed, en vert. M. Fiedrowicz, Gregor der Grosse, Evangelienhomilien 2, Fontes Christiani 28 (Freiburg im Breisgau 1998), 740-765, aldaar 743.

37 Een ander duidelijk voorbeeld wordt gegeven in K. O'Brien O'Keeffe, 'The use of Bede's writings on Genesis in Alcuin's Interrogationes', Sacris Erudiri 22 (I979), 463-483, aldaar 477-479.

38 Gregorius, Dialogorum Libri Quattuor, ed. en vert. A. de Vogüé en P. Antin, Grégoire le Grand: Dialogues II, Sources Chrétiennes 260 (Parijs I979); GSR I.4, pp. II8-121 is gebaseerd op Dialogen 3.26, pp. 366-373, GSR 2.2, pp. I50-I53 op Dialogen 2.7, pp. I56-I6I, GSR 2.3 op Dialogen 1.9, pp. 76-93 en GSR 2.7 en (in mindere mate) 2.8 op Dialogen 2.II, pp. I72-I75. 
moet zijn geweest bij de auteur. ${ }^{39}$ Beda was op zijn beurt sterk. beïnvloed door Gregorius. ${ }^{40}$ Het valt aan te nemen dat ook Beda's gedachtengoed terug te vinden is in de GSR. Het kan dus de moeite waard zijn om, als het erom gaat de gedachtenwereld van de auteur te begrijpen, ook Beda's exegetische werken te betrekken bij een studie naar het Bijbelgebruik in deze bron.

Het moet overigens niet vergeten worden, dat de GSR hoofdzakelijk bedoeld was voor de gemeenschap van Redon zélf, voor die monniken die op dezelfde manier als de auteur waren opgeleid, met dezelfde bibliotheek en hetzelfde curriculum. Voor hen zou de GSR meer zijn dan alleen een historie. Het werk was weliswaar, zoals Smith betoogt, ten dele bedoeld om het klooster aan de buitenwereld te presenteren als "the most potent shrine in western christendom", maar het is ook een belangrijke manier om de zelfperceptie van deze monniken in de late negende eeuw te peilen. ${ }^{41}$ De signalen die hiertoe gegeven werden, in de vorm van bijbelcitaten, bieden een interessante mogelijkheid dat te doen.

\section{Redon en de wereld, Redon in de wereld}

Uit het beeld dat de auteur van de GSR zijn gemeenschap wilde meegeven van wat er zoal gaande was buiten de muren van het claustrum, blijkt dat het te ver zou gaan om Redon als een zuiver 'Bretons' klooster te zien. Het was voor hem van groot belang duidelijk te maken dat het keizerlijke, Karolingische gezag zo slecht nog niet was. Als het Conwoion bijvoorbeeld eindelijk is gelukt om de steun van Lodewijk deVrome te verkrijgen, is het eerste gevolg daarvan dat de keizer het klooster in bescherming neemt tegen de Frankische edelen die blijkbaar op diens bevel Bretagne waren binnengevallen en de gemeenschap bedreigden. ${ }^{42}$ Er zat echter meer achter dit voorbeeld dan alleen maar bescherming tegen kwaadwillende Frankische edelen.

Vlak voordat Conwoion voor de eerste keer naar het hof reist om keizerlijke steun af te smeken, vertelt de auteur, krijgt Redon te maken met twee machtierns, Risweten en Tredoc. De eerste confronteert Conwoion en zijn prior Louhemel als ze in een naburig dorp als arbiter in rechtszaken optreden met een claim op het land dat hem rechtens zou toebehoren. Als de monniken van Redon hieraan niet toe willen geven, neemt hij ook genoegen met één villa, een paard en een harnas. Conwoion weigert beleefd, en uiteindelijk gaat Risweten weg met twintig solidi, iets wat hem op een uitbrander van een familielid, Tredoc, komt te staan. Voordat de machtierns echter verdere actie kunnen ondernemen, vallen de Franken Bretagne binnen. ${ }^{43}$ De twee boosdoeners

39 Zie boven, p. 6, noot 25 .

40 William D. McCready, Miracles and the Venerable Bede (Toronto I994), 105-106 wijst hier op, met speciale andacht voor de invloed van Gregorius' Homeliae in Evangelia op Beda's In Marci Evangelium. Cf. ook in het huidige artikel Pp. I7 en 21 .

41 Smith, 'Aedificatio sancti loci', 387.

42 GSR, I.II, I4O-I43-

43 Dit is een andere veldtocht dan de eerder genoemde, onder Lodewijk de Vrome. Chronologisch gezien komt deze zelfs later, aangezien hij volgens de auteur bevolen was door Karel de Kale. Voor de opbouw van het verhaal in boek I zit deze veldtocht echter wel op zijn plaats, zoals later duidelijk gemaakt zal worden. In dit geval is de veldtocht een dets ex machina, een indicatie dat het klooster goddelijke bescher- 
besluiten dat er daar meer te halen valt en ze sluiten zich aan bij het Bretonse leger. Hoe de slag verder verloopt, vertelt het verhaal niet, maar wel dat Risweten en Tredoc op het moment suprême vluchten voor de strijd en zich in een schuurtje verstoppen alwaar ze verraden worden door een dorpeling. Hun ontdekking betekent meteen ook hun droevig einde, en het verhaal sluit met de opmerking dat een welwillende boer het geld dat Redon hun had betaald weer teruggeeft aan Conwoion. ${ }^{44}$

Ogenschijnlijk is dit een vrij simpel verhaal, dat als waarschuwing moest dienen voor al te hebzuchtige edellieden en dat moest laten zien hoe het afliep met diegenen die Redon probeerden dwars te zitten. Als zodanig heeft het ook wel degelijk een basis in de harde realiteit van de late negende eeuw in Bretagne. Interessanter is echter om te zien hoe dit verhaal, in samenspraak met de hoofdstukken die volgen, de visie van de auteur op gerechtigheid en de rol van de keizer daarin weergeeft. Hier komen de gebruikte bijbelcitaten van pas, die op de volgende wijze in het begin van het verhaal verwerkt zijn:

Het vat van uitverkiezing en onderwijzer der volkeren, de apostel Paulus, spreekt tot alle gelovigen, zeggende: Allen die in Christus vroom willen leven zullen vervolgd worden vanwege de gerechtigheid. En ook onze heer Jezus Christus zelf heeft in het evangelie tot zijn discipelen gezegd: Als ze mij hebben vervolgd, zullen ze ook jullie vervolgen; maar houd moed: ik heb de wereld overwonnen. ${ }^{45}$

En verderop:

Toen werd vervuld wat door de profeet al was verteld, zeggend: Wie een kuil graaft voor zijn naaste, valt daar als eerste in. ${ }^{46}$

Het eerste citaat van dit hoofdstuk is een combinatie van 2Tim 3:I2 en Mat 5:Io. Deze combinatie van citaten heeft verschillende effecten op de manier waarop we het verhaal kunnen interpreteren. Buiten de implicatie dat de daden van Risweten en Tredoc inderdaad onrechtvaardig zouden zijn, wijst het namelijk ook op het feit dat de monniken 'gelukzalig' zijn. Ze worden in dit verhaal immers vervolgd omwille van de (menselijke) wet. Het gaat hier dan om de menselijke regel die zegt dat Risweten zijn land terug zou moeten krijgen. Dat kan echter niet. Het land is, volgens Conwoion, inmiddels toegezegd aan Christus, en valt daarmee buiten het menselijke recht. Het heeft geen zin meer om de wet tegen de heiligen te gebruiken. De monniken, die dus bijna letterlijk in

ming geniet; aan het eind van dit boek dient de oorlog als een pretext om de macht van Lodewijk de Vrome te tonen. In deze is het interessant om op te merken dat van geen van beide veldtochten een uitslag genoemd wordt.

44. GSR, I,7, 126-I3I.

45 GSR, 1,7, I27: Uas electionis et doctor gentium Paulus apostolus cunctis fidelibus alloquitur, dicens: 'Ommes qui pie uolunt uinere in Christo persecutionem patiuntur propter iustitiam'. Nam et ipse dominus noster Iesus Christus in euangelio suis discipulis dixit: 'Si me persecuti sunt, et uos persequentur: tamen confidite, quia ego uici mundum'. De bijbelcitaten, in de Nederlandse versie uit de Willibrordvertaling, zijn cursief aangegeven.

46 GSR 1,7, I31:Tunc adimpletum est quod dictum est per prophetam dicentem:'Qui fodit foueam proximo suo, primus incidit in illom?. 
Christo leven, worden vervolgd omwille van het recht, waar de goddelijke rechtvaardigheid uiteindelijk zou zegevieren.

Dit wordt nog eens versterkt als gekeken wordt naar een tweede keer dat het citaat uit de bergrede van Matteüs, wordt aangehaald. Dat gebeurt in hoofdstuk I.9, als Conwoion ten tweede male poogt om keizerlijke steun te verkrijgen. Deze keer wordt erbij vermeld dat zij die vroom willen leven ook zalig zijn en dat ze deel zullen hebben aan het koninkrijk der hemelen, maar de redenering is wel omgedraaid: samen met een tweede citaat, uit 2 Tim 2:5, "Iemand die aan sport doet, zal geen prijs winnen als hij zich niet aan de spelregels houdt", blijkt dat de abt juist een poging onderneemt om zich legitiem, volgens de regels, aan de Karolingers te binden. Het verschil zit hem in het feit dat het deze keer om de keizer gaat, en niet om twee machtierns die de veiligheid van het klooster direct bedreigen, en natuurlijk dat de regels (van de keizer) in het voordeel van het klooster werken. Het lijden van de monniken in dit geval is veroorzaakt door het feit dat de keizer, in deze fase van het verhaal nog gepresenteerd als de farao uit Exodus, maar ook als vertegenwoordiger van de aardse ecclesia en iustitia, nog niet wil luisteren naar de bede van Conwoion. ${ }^{47}$ De serie petities aan de keizer, aldus de abt, is zo ook een beproeving van volharding die door God is geïnstigeerd: “...en [Conwoion] sprak tot zijn broeder Cumdeluc:'De Heer heeft het hart van de keizer nog niet geopend, opdat hij ons iets zou schenken; want het hart van de koning is in de hand van God" "48 Het feit dat Conwoion midden in zijn uitspraak de keizer tot koning degradeert, kan hier een signaal zijn dat de auteur Spr 2I:I aanhaalt, of dat hij verwijst naar Beda's In Proverbia Salomonis, waarin een vorm van dit vers wordt gebruikt die dichter tegen die in de GSR aanligt. ${ }^{49}$ Hierin wordt de auteur overigens ondersteund door de betekenis die Gregorius de Grote aan het citaat uit 2 Tim geeft in zijn Homeliae in Evangelia, namelijk dat het leven op Aarde slechts bestaat uit een serie beproevingen. ${ }^{50} \mathrm{Niet}$ alleen de pogingen om bij de keizer in de gunst te geraken vormen zo'n beproeving. De moeilijkheden met de twee machtierns zijn dat net zo goed.

Dit brengt ons dan bij het tweede citaat in dit hoofdstuk, wederom een samenstelling, maar deze keer van twee verzen uit het Evangelie van Johannes, i5:20 en 16:33:

47 GSR 1.10, I36-137, waarin Ex. 3:7-10 en 5:1 worden aangehaald; over de rol van de keizer als bron van iustitita in de negende eeuw, zie J.L. Nelson, 'Kings with justice, kings without justice: an early medieval paradox' in: La giustizia nell'alto medioevo (secoli IX-XI), Settimane di Studi del Centro Italiano di Studi sull'Alto Medioevo 44 (Spoleto 1997), 797-825.

48 GSR I.9, 134-135: “...dixitque confratri suo Cumdeluc: 'Nondum aperuit Dominus cor imperatoris ut daret aliquid nobis, quia cor regis in manu Dei est"'. Het is niet duidelijk of deze Cumdeluc dezelfde monnik is als die waarvan sprake is in GSR 2,3 (pp. I $52-155$ ) en hierboven, op p. I.

49 Spr 21:I, "Sicut divisiones aquarum ita cor regis in manu Domini quocumque voluerit inclinabit illud" - "Het hart van de koning is als een waterstroom in de hand van de Heer; Hij leidt het waarheen het hem behaagt". Deze allusie is overigens niet als zodanig herkend door Brett of Heinemann; Beda, In Salomonis proverbia libri III, ed. D. Hurst, CCSL II9B (Turnhout 1983), 2:21, p. I08: "Sicut diuisiones aquarum ita cor regis in manu Dei”. Zie over het gebruik van de Vetus Latina en Beda's In Proverbia ook beneden, pp. I4-Is.

50 Gregorius, Homeliae in Evangelia, 2:37:I "Sed ad magna praemia peruenire non potest, nisi per magnos labores. Vnde et Paulus egregius praedicator dicit: Non coronabitur nisi qui legitime certauerit. Delectat igitur mentem magnitudo praemiorum, sed non deterreat certamen laborum." - "Maar hij kan de grote prijs niet bẹreiken, behalve door grote werken. Hierom zegt Paulus de voorteffelijke prediker: ${ }^{\text {Hij }}$ wordt niet gekroond, behalve als hij zich aan de spelregels houdt'. Moge de derhalve geest genoegen scheppen in de omvang van de prijzen, maar niet terugschrikken voor de strijd van de werken". De auteur van de GSR volgt overigens de vorm van het citaat uit dit werk. 
"Als ze mij hebben vervolgd, zullen ze ook jullie vervolgen" "Maar houd moed: ik heb de wereld overwonnen". Ditmaal is het het commentaar dat Augustinus hierop biedt in zijn In Iohannis Evangelium Tractatus dat ons verder helpt. Voor deze kerkvader, die overigens ook Mat 5: Io weer aanhaalt, staat iustitia namelijk gelijk aan liefde voor Christus, en degenen die die liefde misbruiken zijn dus dubbel zo slecht af. Daarna gaat hij verder, en aan de hand van Joh I5:I9 en 20 legt hij uit dat de echte gelovigen in feite buiten de wereld staan, en niet aan menselijke regels onderhevig zouden moeten zijn. ${ }^{51}$ Gezien de positie van deze citaten binnen het verhaal, wordt het thema van de vervolgingen hier dus voortgezet, en als het klopt dat de auteur hier Augustinus' redenering volgt, dan wordt de liefde voor Christus die de monniken hebben hier alleen maar sterker door benadrukt De positie van Redon is hiermee door de auteur verder verstevigd: menselijke wetten zijn niet op hen van toepassing, juist omdat de monniken zo sterk zijn in het geloof en de liefde van Christus dus dubbel en dwars verdiend hebben. Dit had hij in hoofdstuk I.I al aangegeven, ook weer met een citaat uit een brief van Paulus: "Er kan geen overeenstemming zijn tussen de kinderen van het licht en de kinderen van het duister, zoals Paulus de apostel getuigt: 'Is er enige overeenstemming tussen Christus en Belial?"'. ${ }^{52}$ Hoewel uit het Cartularium van Redon meermalen blijkt dat de monniken in de praktijk geen problemen hadden met de geldende regels omtrent landbezit, was het in het ideaal zoals beschreven in de GSR belangrijker om te laten zien dat zij het goddelijke gelijk aan hun kant hadden. De auteur speelt in dit hoofdstuk dus met een dubbele betekenis van iustitia: hij gebruikt het in de "juridische" zin des woords, maar, met de bijbelcitaten als leidraad, ook om een diepere betekenis aan dit verhaal mee te geven. De machtierns maken gebruik van het menselijke recht, maar aangezien zij iustitia moeten ontberen, loopt het, in tegenstelling tot de monniken, slecht met ze af.

En zo kwamen Risweten en Tredoc in de kuil terecht die zij zelf gegraven hebben, iets wat de auteur ons door middel van Sir 27:29, het derde geciteerde bijbelvers in dit hoofdstuk, nog eens extra duidelijk maakt. Hun zoektocht naar aardse rijkdom over de ruggen van anderen - hun naasten - eindigt met hun eigen dood. In dit geval is het lastig de herkomst van dit citaat precies te achterhalen. Het lijkt erop dat Redon dit Bijbelboek in een andere versie dan de Vulgaat op de plank had staan, getuige ook het

51 Augustinus, In Iohannis Euangelium Tractatus, 88: I, ed. R. Willems, Corpus Christianorum, Series Latina 36 (Turnhout 1954), 546-548, aldaar 546. Een mogelijke andere bron voor deze twee verzen wordt geboden door Alcuin, die de GSR gebruikte vorm van Joh I6:33 ook veelvuldig toepast in zowel zijn brieven als zijn Commentaria in Sancti Joannis Evangelium. Aangezien hij in de bewuste passage van zijn beroemde uitleg van dit evangelie aan Gisela en Rotruda echter gebruik maakt van het werk van Augustinus, lijkt het in deze gerechtvaardigd om aan te nemen dat de auteur van de GSR hoe dan ook de uitleg van de oude kerkvader heeft gevolgd. Interessant is overigens wel om te zien dat de precieze formulering van Joh I6:33 in de GSR, met gebruikmaking van "confidite", verder alleen maar voor lijkt te komen in werken van Alcuin - misschien een indicatie dat in Redon een Alcuin-bijbel aanwezig is geweest. Cf. Alcuin, Commentaria in Sancti Joannis Evangelium in:J.P. Migne ed., Patrologia Latina 100 (1863), kol. 724-1008, aldaar kol. 947 en 959-960, alsmede, zijn brieven, in Ernst Dümmler ed., Monumenta Germaniae Historica Epistolae 4 (Epistolae Karolini Aevi 2) (Berlijn I895), I-48I, aldaar pp. 254 (brief I56), 300 (brief I8I), 454 (brief 295) en 459 (brief 300 ). In alle gevallen lijkt Alcuin dit citaat te gebruiken om de ontvanger van de brief een hart onder de riem te steken.

GSR I.I, 106-I07; 2 Kor 6:15. 
andere citaat uit Sirach in de GSR..$^{53}$ De tekst lijkt op een oudere Bijbelvertaling gebaseerd te zijn die ook zijn sporen heeft nagelaten in Defensor van Ligugé's Liber Scintillarum, Ambrosius Autpertus' Expositionis in Apocalypsin libri 10, en het Breviarium Romanum. ${ }^{54}$ Opmerkelijk is de overeenkomst met Beda's In Proverbia Salomonis Libri III. Niet alleen vertoont de formulering die de auteur van de GSR heeft gebruikt, een duidelijke gelijkenis met die van deze kerkvader, maar we weten dat de auteur van de GSR Beda's werk veelvuldig gebruikte. ${ }^{55}$ De nadruk ligt via deze associatie op het idee dat zij die rechtvaardig handelen, hun dood niet hoeven te vrezen, hetgeen blijkt uit het feit dat Beda dit vers gebruikt bij zijn uitleg van Spr 29:6, "Voor de voeten van de slechte mens ligt een valstrik, maar de rechtvaardige juicht en is blij", waarover hij zegt: "Dus de valstrik van de zonde doet de rechtvaardige geen kwaad, zelfs niet als hij [hem] lichamelijk vernietigt". ${ }^{56}$ Direct daarop gaat Beda overigens over op Spr 29:9:"Als een wijs man een rechtszaak heeft met een dwaas, kan hij zich kwaad maken of lachen; er komt geen oplossing"; misschien zijn deze associaties toch weer een aanwijzing dat de auteur deze spreuk aanhaalde met Beda in het achterhoofd?57

De bijbelcitaten in dit hoofdstuk hebben laten zien, dat er voor de auteur een duidelijk onderscheid bestond tussen de regels die golden voor zijn gemeenschap en de regels die golden voor de wereld daarbuiten. ${ }^{58}$ Preciezer gezegd: de door mensen gemaakte wetten golden in principe niet voor Redon, aangezien het klooster goddelijke bescherming genoot. Zolang de monniken zich voorbeeldig zouden gedragen, zou het de gemeenschap voor de wind blijven gaan. De zo gewilde bescherming door de Karolingische keizers, de rode draad door Boek I, lijkt hierop een uitzondering te zijn, maar dat geldt in feite alleen maar wanneer de GSR wordt gezien als een zuiver "politiek" geschrift, bedoeld voor de buitenwereld en niet voor de monniken zelf. In dat geval zou de uiteindelijk positieve waardering van Lodewijk deVrome gezien kunnen worden als een steunbetuiging aan iemand bij wie voordeel te halen viel. Blijkbaar was de bedoeling van de auteur echter ook om een daadwerkelijk positief beeld van de keizer te scheppen, aangezien deze in de late negende eeuw toch werd gepresenteerd - geïdealiseerd - als leider van de gehele Christelijke wereld. ${ }^{59}$ In die zin stond hij dus voor de

53 In GSR 3.I, 192-193, wijkt Sir 44:14-15 ook af van de versie zoals die in deVulgaat te vinden is.

54 Voor het besproken citaat, zie Defensor Locigiacensis, Liber Scintillarum, ed. en vert in H.B. Rochais, Defensor de Ligugé, Livre d'étincelles II, Sources Chrétiennes 86 (Parijs 1962), c.45, I0. De belangrijkste parallel voor Sir 44:I4 is te vinden in Ambrosius Autpertus, Expositionis in Apocalipsin, 5:II:9, ed. R. Weber, CCCM 27 (Turnhout 1975), 425, hetgeen interessant is, aangezien dit werk in San Vincenzo al Volturno is geschreven, en het bewuste hoofdstuk in de GSR handelt over een monnik "in Spolitana provincia", die op pelgrimstocht naar Redon gaat. Of er ook daadwerkelijk een link bestaat tussen Autpertus en de GSR zal nader onderzoek moeten uitwijzen. Met dank aan de digitale "editie" van de Vetus Latina op de website van Brepols, http://www.brepolis.net.

55 Beda, In Proverbia, 3:29, p. I38: Nam qui fodit foueam proximo suo incidet in eam ipse ut alibi dictum est. Vergeleken met de formulering in de Vulgaat, "qui foveam fodit incidet in eam", valt op dat de woordvolgorde anders is, en de toevoeging "proximo suo" ontbreekt.

56 Beda, In proverbia, 3:29, "Non ergo iusto laqueus peccantium, etiamsi corporaliter perimat, nocet."

57 Spr 29:9: "Vir sapiens si cum stulto contenderit sive irascatur sive rideat non inveniet requiem"

58 C. M. de Jong, 'Old law and new-found power: Hrabanus Maurus and the Old Testament' in:J.-W. Drijvers e.a. (eds.), Centres of learning: learning and location in pre-modern Europe and the Near East (Leiden I995), I6I-I76.

59 R. Le Jan, 'Justice royale et pratiques sociales dans le royaume franc au IXè siècle' in: La giustizia nell'alto medioevo (secoli V-VIII), Settimane di Studi 42 (Spoleto 1995), 47-85, aldaar 53-54. 
auteur van de GSR, net als voor de gemeenschap van Redon, boven de menselijke gerechtigheid. Zijn bescherming was de best mogelijke benadering op aarde van de goddelijke bescherming die Redon al genoot, met dien verstande dat vijanden van het klooster deze bescherming ook zouden herkennen, waardoor ze minder geneigd zouden te zijn om hun machtswellust op Redon te botvieren. Door de Karolingers in een positief licht te zetten, maakt de auteur duidelijk dat de steun van de monniken aan de Frankische keizers meer was dan louter politiek opportunisme. Hij wilde dat zijn toehoorders de keizer zouden geven wat des keizers was.

Dat de auteur deze visie aanhing lijkt geillustreerd te worden door hoofdstuk I.II, waarin niet God, maar Lodewijk een edelman verhindert om Redon dwars te zitten. Nadien lijken de conflicten met de lokale adel ook voorbij. Boeken 2 en 3 handelen verder niet meer over conflicten tussen Redon en de buitenwereld, maar over de gevaren die voor elke afzonderlijke monnik op de loer lagen en de beloning die hem te wachten zou staan als hij die het hoofd zouden weten te bieden. Hoe de auteur daar vorm aan gaf en welke boodschap hij zijn publiek in deze wilde meegeven, wordt misschien wel het beste geillustreerd aan de hand van hoofdstuk 2.I, waarin de abt Conwoion een blinde geneest.

\section{Een spiegel voor monniken}

Waar in het eerste boek van de GSR vooral de politieke kwaliteiten van Conwoion werden belicht, handelt het tweede boel- meer over de heiligheid en de voorbeeldfunctic van deze ideale abt en zijn ideale monniken. De gemeenschap geniet de bescherming van de machtigen der aarde, en volgens de auteur was het derhalve tijd dat "de Heer zijn heiligheid aan het volk zou tonen". ${ }^{60}$ Dat gebeurt wanneer een boer, Goislenus, plotsklaps het licht in zijn ogen verliest, en zijn eigen leenheer, de heilige Philibertus, beschermheer van het klooster te Noirmoutier, hem geen soelaas kan bieden. $\mathrm{Na}$ een visioen trekt Goislenus naar Redon, alwaar Conwoion eerst beleefd weigert hem te helpen, omdat het niet aan monniken is om blinden te genezen. Wanneer de boer echter weigert te vertrekken, laat Conwoion hem - onder begeleiding van de auteur, die als handelende persoon in dit verhaal optreedt - zijn gezicht spoelen in het bekken waar de priesters na de eucharistie hun handen in hebben gewassen, met de boodschap dat het resultaat "zou gaan overeenkomstig zijn geloof". ${ }^{11}$ Het middel werkt, en nadat er een grote hoeveelheid bloed uit de oogkassen en neus van Goislenus is gestroomd, kan hij weer zien.

Uiteraard dient dit verhaal in eerste instantie als een verheerlijking van Conwoion, en om de superioriteit van Redon ten opzichte van Noirmoutier te benadrukken. Daarnaast is het, als eerste wonderverhaal in de GSR, ook bedoeld om het publiek de ogen te openen - het verhaal over de relieken van St. Hypothemius begint ook met de genezing van een blinde, en dankzij die van St. Marcellinus kan een stomme herdersjongen weer praten om de grootsheid van de heiligen te verkondigen. ${ }^{62}$ Het verhaal is

60 GSR 2:I, I48-I49.

61 Mat 9:29.

62 GSR, 2:9, 170-175; GSR, 3:2, 192-195. 
echter ook een kort portret van de ideale monnik, gepersonifieerd door Conwoion en, in mindere mate, de auteur zelf. Samen zijn zij gastvrij, vol van naastenliefde, gehoorzaam, en bovenal nederig genoeg om, in de woorden van de Regula Benedicti, "niet heilig genoemd te willen worden voordat men dat is, maar om eerst heilig te zijn, opdat men waarlijk zo genoemd mag worden". ${ }^{63}$

Aan de basis van dit portret liggen uiteraard de verhalen waarin Christus één of meerdere blinden geneest, zoals die voorkomen in de evangeliën. ${ }^{64}$ De auteur heeft zich niet aan één specifiek verhaal verbonden, maar neemt elementen uit de verschillende versies over. Zo is het gegeven dat de blinde zijn gezicht moet wassen om de genezing te bewerkstelligen, uit Joh 9:7, in gewijzigde vorm terug te vinden in de GSR. Interessant hierbij is dat in de Bijbel wordt vermeld dat deze man blind is, daar "de daden van God moeten in hem openbaar worden". ${ }^{65}$ Dit gegeven zien we ook terug in de door de auteur van de GSR gebruikte citaten voor dit hoofdstuk. ${ }^{66}$ Een ander belangrijk plotelement, dat de genezing zou gebeuren "secundum fidem tuam", roept een associatie op met Mat 9:29, waar Christus dit zegt tegen de twee mannen die hij geneest.

Hier is echter ook de invloed van Beda op het gedachtengoed van de auteur goed te zien. Dit citaat, uitgesproken door de abt, is terug te vinden in diens In Lucae Evangelium en In Marci Evangelium, waarvan de eerste in ieder geval door de auteur is gebruikt. ${ }^{67}$ Beda gebruikt de clausule over het geloof van degene die om genezing vraagt ter illustratie van het verhaal dat de apostelen niet in staat waren om een duivel uit te drijven. ${ }^{68}$ Dit had volgens hem niets te maken met de incompetentie van de apostelen, maar alles met het gebrek aan geloof van degenen die de genezing wensten: "Impliciet beklaagde hij (= de vader van een bezeten jongen (Luc 9:38-40)) door dit te zeggen de apostelen, terwijl de onmogelijkheid te genezen soms niet ligt aan de onkunde van de genezer, maar aan het geloof van degenen die genezen worden, zoals wordt verteld door de heer, zeggende: "Het moge je gaan overeenkomstig je geloof". ${ }^{69}$ De aanpak van Conwoion in dit verhaal heeft eenzelfde effect: het was niet de bedoeling dat Goislenus, of het publiek, zou denken dat de abt de genezing al dan niet zou voltrekken. Hij kon hen alleen maar op het juiste pad helpen, gelijk de goede herder die hij hoort te zijn. Zijn nederigheid belette hem om te beweren dat hij zelf de macht zou hebben die Goislenus eerst in hem zag.

Dit gegeven zien we ook terug in de andere wonderverhalen in de GSR, en dan met name daar waar het wonder wordt verricht door een nog levende monnik. Over

$63 R B, 4: 62$ in: Die Benediktusregel, 104-IOS.

64 Mat 9:27-3I en 20:29-34; Mar 8:22-26 en 10:46-52; Luc I8:35-43; Joh 9:I-I2.

65 Joh 9:3

66 Zie onder, pp. 17-19.

67 Beda, In Marci Evangelium Expositio en In Lucae Evangelium Expositio, ed. D. Hurst, CCSL I20 (Turnhout, I960). In beide gevallen staat de bewuste passage in boek 3, caput 9, en deze luiden respectievelijk: "Quod autem ait, et dixi discipulis tuis ut eicerent illum, et non potuerunt, latenter accusat apostolus cum impossibilitas curandi interdum non ad imbecillitatem curantium sed ad eorum qui curandi sunt fidem referatur dicente domino: fiat tibi secundum fidem tuam." (In Marci, 427-648, aldaar 547-548) en "Latenter hoc dicto accusat apostolos cum impossibilitas curandi interdum non ad imbecillitatem curantium sed ad eorum qui curandi sunt fidem referatur dicente domino: fiat tibi secundum fidem tuam." (In Lucae, I-425, aldaar 208).

68 Mc. 9:17 en Luc. 9:40.

69 Vertaling van de hierboven geciteerde passage uit In Lucae. In het Evangelie van Marcus blijft het overigens bij deze vertrouwenskwestie, terwijl Lucas het verbindt met het lijden van Christus en het onbegrip van de mensen daarover. 
Condeluc, de tuinman, wordt bijvoorbeeld nog gemeld dat hij na zijn rupsenwonder niet trots ging doen, maar dat hij "in opperste heiligheid volhardde". En waar Conwoion niet vroeg het wonder stil te houden - wat wel gebeurde in de Evangeliën van Marcus en Matteüs - was dat wel het verzoek van twee andere monniken nadat ze tijdens een voetwassing een verlamde man hadden genezen. Niet dat dit enig effect lijkt te hebben gehad, overigens. De genezen man "begint uit zichzelf door het hele huis, van hier naar daar te rennen", net zoals de door Christus genezen blinden alles tóch doorvertellen. ${ }^{70}$ Het lijkt dus niet meer dan valse bescheidenheid, maar het is wederom niet alleen een voorbeeld van het veelvuldige bijbelgebruik in de GSR, maar ook, zoals nu getoond zal worden, van de invloed van Gregorius de Grote op de interpretatie van de auteur.

In Dialogen van Gregorius de Grote wordt bisschop Bonifacius van Ferenti opgevoerd, die een wonderbaarlijke vermenigvuldiging van wijn weet te bewerkstelligen. ${ }^{71}$ Ook hier wordt de aanwezigen op het hart gedrukt dit wonder toch vooral stil te houden, waarop Gregorius' gesprekspartner het verhaal uit de evangeliën te berde brengt en de vraag opwerpt: waarom toch die geheimhouding? Het antwoord is in feite simpel: volgens de kerkvader was alles wat Christus deed, een voorbeeld, dus zowel de genezing als de geheimhoudingsplicht uit bescheidenheid. Het was daarna aan God om ervoor te zorgen dat dit alles toch bekend zou worden, anders zou de les over liefdadigheid toch verloren gaan. Op diezelfde manier zorgde de auteur van de GSR er dus voor dat de goede daden van de monniken, ondanks hun eigen nederigheid, bewaard zouden blijven als een permanent voorbeeld voor zijn publiek. Zoals we zullen zien, dient het viertal expliciete bijbelcitaten in dit hoofdstuk voornamelijk om juist die boodschap duidelijk te maken. Alle vier staan ze aan het begin van het hoofdstuk, op een manier die vergelijkbaar is met die in GSR I,7:

\section{De Heer zegt in het Evangelie: Niemand steekt een lamp aan om die onder de koren- maat te zetten, maar wel op een kandelaar; dan ziet iedereen die binnenkomt het licht. En elders zegt de Heer zelf: Je oog is de lamp van je lichaam; is je oog helder, dan is ook je lichaam helemaal verlicht. Is het echter slecht, dan is het ook duister in je lichaam. En de profeet roept, op wonderlijke wijze zeggend: Mensenzonen, weet wel: de Heer doet wonderen voor zijn heiligen en elders: Ontzagwekkend is God in zijn heiligen. ${ }^{72}$}

Het eerste citaat komt voort uit Luc II:33, hoewel nagenoeg dezelfde bewoordingen ook in de Bergrede, Mat $5: 15$ voorkomen. ${ }^{73}$ Voor Lucas lijkt de uitspraak te doelen op het gegeven dat de goedheid en het geloof van de mens zich hoe dan ook zullen manifesteren, terwijl in de Bergrede van Matteüs de toehoorders te horen krijgen dat ze de

70 GSR, 2,4, 156-16.1.

71 Gregorius, Dialogorum Libri Quattuor, 1.9, pp. 76-93.

72 GSR 2.I, I46-147: Dominus dicit in Euangelio: 'Nemo accendit lucernam et ponit eam sub modio, sed super candelabrum, ut qui ingrediuntur lumen videant'. Et iterum ipse Dominus ait: 'Lucerna corporis tui est oculus tuus. Si oculus tuus fuerit simplex, totum corpus tuum lucidum erit; si autem nequam fuerit, totum corpus tuum tenebrosum erit'. Et propheta proclamat mirabiliter dicens: 'Filii hominum, scitote quia Dominus sanctos suos mirificauit'. Et iterum: 'Mirabilis Deus in sanctis suis'.

73 Brett identificeert het eerste citaat met Luc 8:16, wat niet geheel onlogisch is, maar mijns inziens komen de bewoordingen van Luc 1r:33 meer overeen met die in de GSR. 
anderen "in het huis" dienen te leiden door het goede voorbeeld te geven. Beide interpretaties zijn van toepassing op Conwoion, wiens goedheid inderdaad manifest diende te worden, en die als abt natuurlijk ook het goede voorbeeld moest geven. ${ }^{74}$ Augustinus breidde deze visie op de abt nog verder uit en maakte het verhaal van een exemplum tot een ware aansporing.Volgens deze kerkvader wordt het licht juist verborgen door degenen die te veel gericht zijn op aardse zaken, en wordt het zichtbaar gemaakt door degenen die "hun lichaam onderwerpen aan de dienst voor de Heer". ${ }^{75}$ In een ander werk lijkt de "kaars" simpelweg te staan voor de goede daden die men kan doen ter inspiratie van anderen - iets wat op zijn beurt ook terugkomt in Gregorius de Grote. ${ }^{76}$ Niet alleen werd van het publiek verwacht dat ze de daden van Conwoion zouden onthouden, ze moesten zijn lichtend voorbeeld ook nog eens volgen.

Direct op dit citaat volgt wederom een vers uit het evangelie van Lucas, waarschijnlijk met de intentie dat deze twee als één geheel beschouwd zouden worden. Het gaat om Luc. II:34, "Je oog is de lamp van je lichaam; is je oog helder, dan is ook je lichaam helemaal verlicht. Is het echter slecht, dan is het ook duister in je lichaam". Het thema van 'zelfverbetering' komt eens te meer naar voren, aangezien het doel van dit citaat lijkt te zijn dat goede daden niet alleen goed zijn als voorbeeld, maar ook voor de weldoener zelf. Met Beda's commentaar hierop wordt echter duidelijk dat de intentie achter de goede werken minstens zo belangrijk is. ${ }^{77}$ Juist de associatie die beide citaten bij goed onderwezen monniken zouden moeten oproepen, maken ze zo geschikt als spiegel voor monniken. Zou bij hen niet ook meespelen dat in de Regula Benedicti staat dat het verlangen heilig genoemd te worden geen rol mag spelen in de gedachten van de monnik? De auteur van de GSR maakt dit eens te meer duidelijk, niet alleen door de woorden en daden van zijn acteurs, maar ook door slim gebruik van de Bijbel en het commentaar daarop - alleen door goed te doen en nederig te blijven kunnen de monniken hun plekje in de gemeenschap verdienen. En later, natuurlijk, in de hemel.

De serie citaten aan het begin van hoofdstuk 2.I wordt afgesloten met een tweetal verzen uit de psalmen, Ps 4:3-4 en 68:36, "Mensen, weet wel: de Heer doet wonderen voor zijn heiligen" en "Ontzagwekkend is God in zijn heiligen", die niet alleen dienen

$74 R B, 2$ in: Die Benediktusregel, 82-93.

75 Augustinus, De Sermone Domini in monte libri duo, 1:6, ed.J.P. Migne, Patrologia Latina 34, 1229-1308, aldaar I237.

76 Augustinus, In Iohannis, 23:3, 232-244, aldaar 233-234. De manier waarop wonderen worden ingezet door Gregorius de Grote is beschreven door William D. McCready, Signs of sanctity: miracles in the thought of Gregory the Great (Toronto I989). Gregorius' visie op goede werken wordt behandeld in Carole Straw, Gregory the Great: perfection in imperfection (Berkeley e.a. I988), m.n. 94-95 en 253-254.

77 Beda, In Lucae, 4:II, p. 239: "Denique praecipit ne opera tantummodo sed et cogitationes et ipsas etiam cordis intentiones mundare et castigare meminerint nam sequitur: lucerna corporis twi est oculus tuus. Corpus quippe dicit opera quae palam cunctis apparent oculum uero ipsam mentis intentionem qua operatur et de cuius merito eadem opera lucis an tenebrarum sint opera discernuntur sicut ipse consequenter exposuit dicens: si oculus tuus fuerit simplex, totum corpus tuum lucidum erit; si autem nequam fuerit, etiam corpus tuum tenebrosum erit." - "Vervolgens vermaant hij [zijn toehoorders] dat zij etaan denken niet alleen de werken, maar ook de overwegingen en intenties van het hart te reinigen en te kastijden, want hij vervolgt: 'Je oog is de lamp van je lichaam'. Het lichaam immers vertelt over de werken die voor iedereen openlijk waarneembaar zijn, maar het oog [vertelt] de intentie zelf van het hart waarmee [die werken] verricht worden. En door die verdienste wordt onderscheiden of deze werken werken van het licht of werken van het duister zijn, zoals $\mathrm{Hij}$ uiteenzet wanneer Hij vervolgens zegt: 'Is je oog helder, dan is ook je lichaam helemaal verlicht. Is het echter slecht, dan is het ook duister in je lichaam'", 
om nog maar eens te benadrukken dat God verantwoordelijk is voor de gedane wonderen, maar ook de gebeurtenissen uit Boek I koppelen aan wat er in Boek 2 komen gaat. Psalm 4 is een korte verhandeling over de macht van de Heer, waarin het publiek op het hart wordt gedrukt altijd op God te vertrouwen. Psalm 68 versterkt dit idee, zeker als daarbij in overweging wordt genomen dat Augustinus de heiligen in deze "lange en moeilijk te begrijpen" psalm ziet als het volk Israël - een associatie die de auteur van de GSR ook niet vreemd is, zeker als bedacht wordt dat in Boek I Lodewijk de Vrome geidentificeerd wordt met de farao uit Exodus, wanneer hij in eerste instantie weigert zijn steun aan Redon te verlenen. ${ }^{78}$ Ook daar ging het erom het lijden van de gemeenschap te beschrijven als iets wat op de lange duur zijn vruchten zou afwerpen. Dat punt is nu bereikt; de eigen heiligen van het klooster kunnen zich manifesteren nu hun tocht door de woestijn is afgelopen. Het is dan ook tijd dat Conwoion de ogen van Goislenus opent, en de auteur die van het publiek.

Het is dan aan het publiek om te trachten net zo goed te doen als de abt. Het hoofdstuk sluit af met nog een laatste citaat, Joh. I4:I2, "De daden die ik verricht, zullen zij ook zelf verrichten; en nog grotere zullen zij verrichten" ${ }^{79}$ Weer is het Augustinus die de leidraad vormde voor de auteur: diens uitleg hiervan, dat iedereen in feite gelijk is voor de Heer, en niemand zichzelf boven zijn stand mag plaatsen, komt bijna letterlijk terug in de Regula Benedicti, waarin de totale onderwerping van de gemeenschap der monniken aan de abt een leitmotiv is ${ }^{80}$ Zoals dit Bijbelcitaat voor Augustinus aangeeft dat iedereen de werken van Christus weliswaar kan evenaren, maar dat dat niet betekent dat diens rol hiermee is uitgespeeld, zo lijkt de auteur van de GSR hiermee te willen zeggen dat de monniken moeten proberen het goede voorbeeld van Conwoion na te streven, maar ondertussen niet te vergeten dat ze absolute gehoorzaamheid aan hem verschuldigd zijn. Juist door die gehoorzaamheid zijn wonderen immers mogelijk. Dit gegeven zien we regelmatig terugkeren in het verhaal. Niet alleen de auteur zelf is

78 Augustinus, Enarrationes in psalmos, 67:40, ed. D.E. Dekkers en J. Fraipont, CCSL 39, (Turnhout I956), 868-900, aldaar 897-898; GSR I.10, I36-1 37.

79 GSR 2.I, I50-I5I: "Christus enim discipulis suis, nec non et cunctis fidelibus, promisit: "Opera quae ego facio et ipsi facient, et maiora horum facient'." - "Want Christus heeft zijn discipelen alsmede alle gelovigen beloofd: 'De daden die ik verricht, zullen zij ook zelf verrichten; en nog grotere zullen zij verrichten'.'

80 Augustinus, In Iohannis, 71:3, 505-507, aldaar 506:"Sed quid est quod sequitur: 'Amen, amen dico uobis, qui credit in me, opera quae ego facio, et ipse faciet, et maiora horum faciet; quia ego ad patrem uado; et quaecumque petieritis in nomine meo, haec faciam. Ut glorificetur pater in flio, si quid petieritis in nomine meo, hoc faciam.' Ergo et illa maiora opera seipsum facturum esse promisit. Non se extollat servus supra dominum, et discipulus supra magistrum; maiora quam ipse facit, dicit eos esse facturos; sed in eis uel per eos se faciente, non ipsis tamquam ex seipsis." - "Maar wat volgt er dan? "Waarachtig , ik verzeker jullie: wie in mij gelooft, zal de werken die ik verricht, ook zelf verrichten; ja nog grotere zal hij verrichten, want zelf ga ik naar de Vader, En wat jullie zullen vragen in mijn naam, zal $1 k$ doen, zodat de vader verheerlijkt wordt in de zoon. Als jullie Mij iets vragen in mijn naam, zal lk het doen.' En zo beloofde $\mathrm{Hij}$ dat Hij zelf al die grotere werken ook zou doen. Laat de dienaar zich zichzelf boven zijn Heer stellen, of de leerling boven zijn meester. Hij zegt dat zij grotere werken zullen verrichten dan $\mathrm{Hij}$ zelf verricht, maar dat alles is doordat $\mathrm{Hij}$ het doet in hen of door hen, en niet alsof zij deze [werken] uit zichzelf verricht hebben."; In de $R B$, zie m.n. caput 5 , De Oboedentia, 3-4, en 7, De Humilitate, I-2: “Omnis, qui se exaltat, humiliabitur, et qui se humiliat, exaltabitur" - "Allen, die zichzelf boven [anderen] stellen, worden vernederd, en wie zichzelf vernedert, zal boven [anderen] gesteld worden", in: Die Benediktustegel, 108-II3 en II6-I33, alsmede Adalbert de Vogüé,'Les conseils évangéliques chez le Maître et Saint Benoît' in: Le Maitre, Eugippe et Saint Benoît: Recueil d'articles, Regulae Benedicti Studia Supplementa 17 (Hildesheim, 1984), 523-537, aldaar 525-527, en, van dezelfde auteur in dezelfde collectie, 'Structure et gouvernement de la communauté monastique chez Saint Benoît et autour de lui', 67 I-706, aldaar 687-688, over de nadruk op gelijkheid van de broeders onderling.

'In divinis scripturis legitur': monastieke idealen en gebruik van de Bijbel 
gehoorzaam als hij voor Conwoion de schaal met water haalt om Goislenus te genezen. Ook anderen houden zich aan de meest basale voorschriften, met miraculeus resultaat. De naastenliefde van de monniken die de lamme genezen, stond al aangekondigd in het bijbelcitaat waarmee dat hoofdstuk begint: "Dit is mijn opdracht: dat jullie elkaar liefhebben met de liefde die Ik jullie heb toegedragen". ${ }^{81}$

Ook Condeluc's wonder, het verjagen van de rupsenplaag uit de kloostertuin, komt voort uit zijn geloof en gehoorzaamheid, zoals ook blijkt uit de citaten in dat verhaal. De eerste twee, uit de evangeliën van Marcus en Johannes, lijken er simpelweg op te wijzen dat zij die geloven, alles kunnen bereiken. Uit de context blijkt echter ook dat dit niet zomaar gaat. Uit Beda's commentaar op het citaat uit Marcus kan het publiek opmaken dat de auteur vindt dat geloof niet vrijblijvend is, en niet te pas en te onpas "ingezet" kan worden. ${ }^{82}$ Er dient te allen tijde tegen de obstakels van de duivel gestreden te worden, zeker in de tuin van het kooster, die volgens Gregorius de Grote symbool stond voor het aards paradijs met alle voor- en nadelen van dien. ${ }^{83}$ Met het commentaar van Gregorius' Homelia in Evangelia wordt dan nog eens extra benadrukt dat alleen op die manier de hemel bereikt kan worden, en niet door er simpelweg om te vragen. ${ }^{84}$

De citaten die gebruikt zijn in hoofdstuk 2.I gaan uiteindelijk meer over de tekst zelf dan over de heiligen die erin beschreven worden. Het zijn aansporingen aan het publiek om de lessen die worden aangeboden, toch vooral serieus te nemen. In dit geval, en in vele andere in de GSR, dienen de verhalen als exempla en de citaten om ervoor te zorgen dat de toehoorders deze verhalen op zichzelf zouden betrekken.

\section{Conclusie}

Het is precies die manier van lezen die de GSR mijns inziens zo fascinerend maakt. Natuurlijk biedt de GSR een interessante kijk op de sociale en politieke realiteit in het grensgebied tussen Bretagne en het Frankische rijk en zijn ze te beschouwen als een mooie monastieke tegentekst tegen de harde werkelijkheid van het Cartularium, maar door de bijbelcitaten geeft het ook een beeld van de manier waarop negende-eeuwse monniken omgingen met hun geloof. De tekst laat zien hoe de monniken de teksten waarmee ze leefden en waren opgegroeid ervoeren, en vooral, hoe een van die monniken hoopte dat hij die kennis kon gebruiken om zijn specifieke boodschap, zijn idealen, door te geven aan de volgende generatie monniken.

Om enig vat te krijgen op die idealen, is het noodzakelijk om ook de patristische context in ogenschouw te nemen, op de manier die al was voorgesteld door Marc van Uytfanghe. Hoewel nog onderzocht moet worden of zijn methode ook op andere Karolingische vitae van toepassing zou zijn, lijkt deze casestudy toch een aardig tipje van de sluier opgelicht te hebben. Als de hierboven voorgestelde methode levensvatbaar is,

81 GSR 2.4, I56-I57; Joh 15:12.

82 Beda, In Marci, 3:11, p. 580 .

83 B. Mïller, 'The diabolical power of lettuce, or garden miracles in Gregory the Great's Dialogues' in: K. Cooper en J. Gregory (eds.), Signs, wonders, miracles: representations of divine power in the life of the church (Woodbridge 2005), 46-55.

84 Gregorius, Homelia in Evangelia, 2:27. 
is, juist doordat de citaten in de GSR zo veelvuldig voorkomen en zo expliciet gemaakt zijn, de verklaring dat dit gewoon de teksten zijn waarmee een monastieke auteur het meeste in aanraking kwam, niet afdoende. Deze auteur volgde niet slaafs de voorbeelden waarmee hij werkte. Hij had een verhaal te vertellen, en gebruikte het hem beschikbare bronnenmateriaal op een uiterst slimme wijze om dat verhaal kracht bij te zetten.

Hoewel het gebruik van de Bijbelcommentaren van Augustinus, Gregorius de Grote en Beda in het klooster Redon niet bewezen kan worden en de precieze bronnen van de auteur van de GSR een heikel punt zullen blijven totdat er een uitgebreider studie naar de inhoud van de bibliotheek van Redon is gedaan, moge het toch duidelijk zijn dat het gebruik van de Bijbel voor de auteur van de GSR en voor zijn beoogde publiek meer behelsde dan uitsluitend de tekst zelf. Onze chroniqueur was inderdaad een "arbeider in de groeve van de heer", in de veronderstelling dat zijn publiek zijn noeste arbeid zou begrijpen en waarderen. ${ }^{85}$ Voor de moderne onderzoeker zijn de commentaren op de Bijbel, zoals men die in de negende eeuw las, minstens zo belangrijk voor de receptie en interpretatie van een tekst alsook voor het vormen een beeld van de leef- en gedachtenwereld van de monniken als de Bijbel zelf. Uit de manier waarop de auteur van de hierboven besproken tekst bron de citaten inleidde en inzette, blijkt wel dat de Bijbel het belangrijkste referentiepunt was én bleef. Het werk van kerkvaders als Gregorius de Grote,Augustinus en Beda was echter minstens zo belangrijk om te bepalen wat de monniken met de Bijbel deden, hoe bepaalde passages functioneerden en hoe dat hun gemeenschap vormde en stuurde - althans, zo lang de GSR het werk deed dat de auteur ervan verwachtte.

Wat zegt dat over de relatie tussen een middeleeuwse auteur en zijn publiek? Over de receptie van oudere bronnen, en over de perceptie van de waarde van nieuw geproduceerde teksten in de Karolingische periode? Dit artikel is uiteraard niet meer dan een voorzichtige poging deze vragen te beantwoorden. Toch, de auteur was een kind van zijn tijd en heeft ons, wellicht zonder het zelf door te hebben, getoond dat het voor hedendaagse onderzoekers van groot belang is om het beoogde publiek en het referentiekader van toen in de gaten te houden. Ook leert hij dat men in de vroege middeleeuwen, net als nu, doorhad dat een tekst ook als acteur binnen een gemeenschap zou kunnen optreden. De GSR was geen fictieve geschiedenis van Redon, en niet het product van de "imaginative memory" van één van de monniken. Ze was bedoeld als een collectie levenslessen, en vooral als een monument voor de stichters van het klooster. Een monument dat de eeuwen beter heeft weten te trotseren dan de gebouwen op die locus sanctus. 
Summary: Rutger Kramer, 'In divinis scritpuris legiutur' : Monastic ideals and the use of the Bible in the Gesta Sanctorum Rotonensium

Taking the late ninth-century Breton Gesta Sactorum Rotonensium as a starting point, this article aims to demonstrate that there is more to the biblical quotations and allusions employed by early medieval hagiographers than initially meets the eye. By juxtaposing the stories these quotations are in with their 'original' biblical context, as well as with patristic commentaries that were en vogue at the time, an attempt is made to show that the use of the Bible was more than merely topical and actually steered the interpretation of the narrative by its intended audience. 


\section{MILLENNIUM}

tijdschrift voor middeleeuwse studies

tweeëntwintigste jaargang | 2008 | nummer 1

Frederik Keygnaert, Van medicijn tot wapen

in de strijd om het kerkbezit 3

Rutger Kramer, 'In divinis scripturis legitur':

monastieke idealen en het gebruik van de Bijbel

in de Gesta Sanctorum Rotonensium 24

Renilde Vervoort, De zaak van de gestolen fallussen 45

Henk 't Jong, De mythe van de vuilnisbelt 68

Boekbesprekingen 92 